BIBL. JORGE WILLIAMS

Copeia - $1979-4$

745.747

THE SOUTHIRMOST YOPULATION OF BLAPOMORPHUS BIIIMEATUS IN

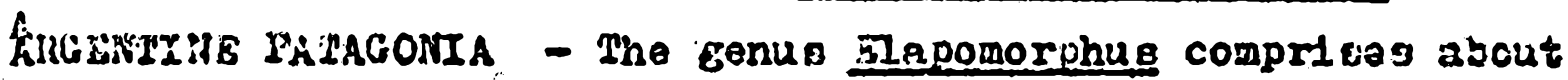
ilino spgeieg, moat of them occurring in tho eastem tropical snd asbtropical regione of Braz1l. Only E.b1lineatue Dumértl, Btbron and Daméril, and R.txtenlox Duméril, Bibron and Duméril extona into the Cisacoan Jowiande and tha Pazaná basin southwer. Ihay arg alav koribera of tho hrgciatins herpetepauna, togathor

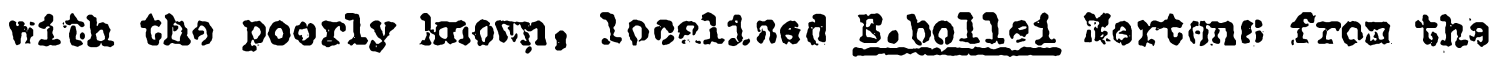

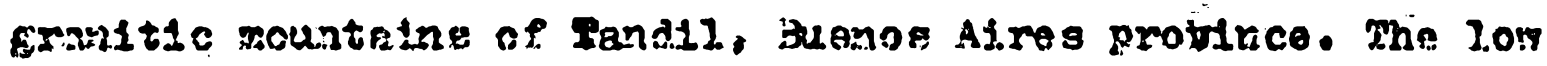
taxonomic rellability of this genus was pointed out by Foters

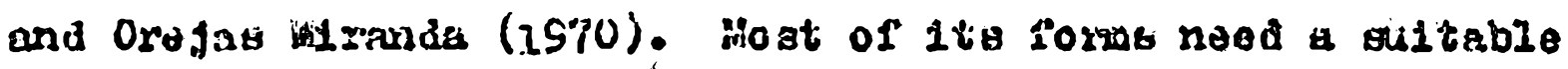

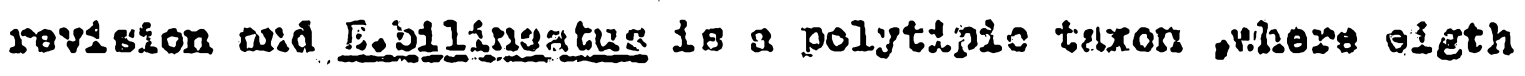

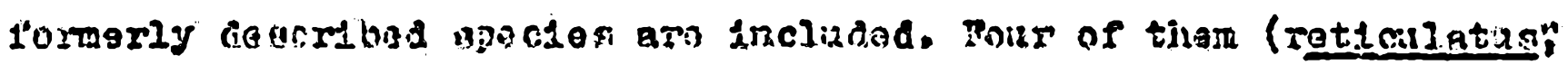

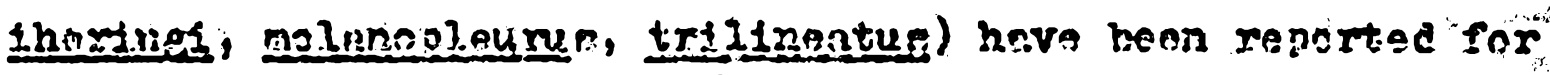
Eastcan Brasilien territorien, one cenerically dobcribed for

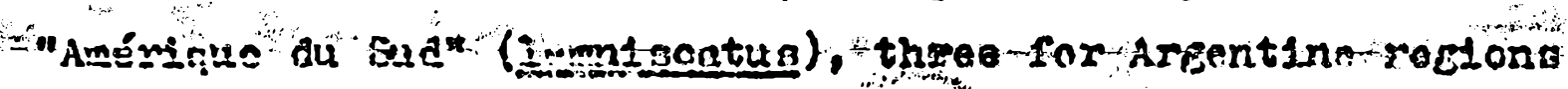

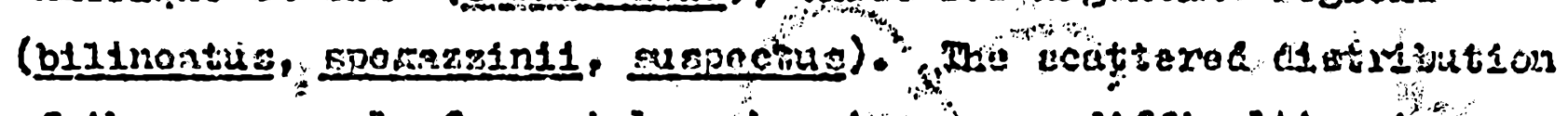

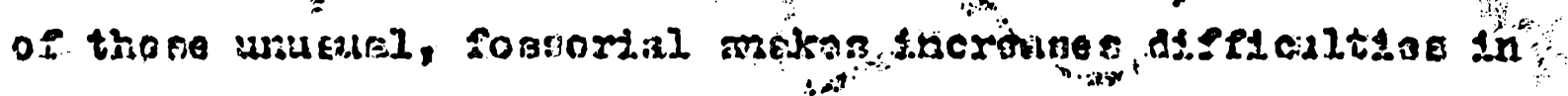
col.loctine and raviaing. Soveral Argentine localities have beon regiatered thmight tho rovigien of the jitierature and

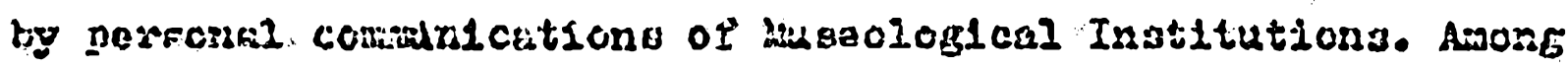
tham we cin regort Corrsontos (terrs tjpica), Fucumen, Gorkotin,

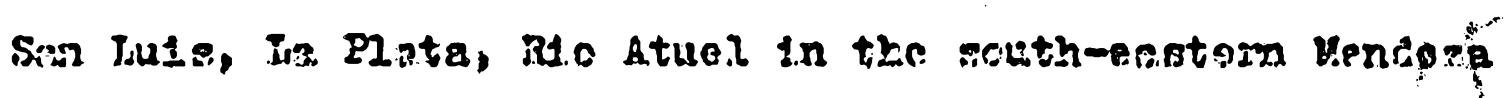
provinse, and Starrs de La Vantans in the soutborm bionon alros province. The iatter was the eouthernout locality yot obearvad, at about 380 50uth latitiado (Gallardo,1970).

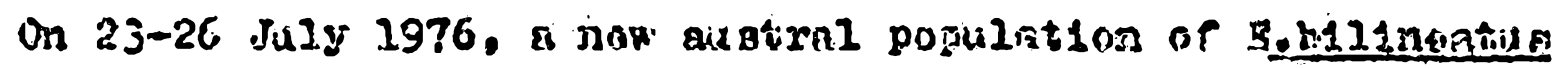
ras, discovered ngar therts Hadrym, ohumit, in the coegtal. Yatagonian rangs of argentina, at about $42^{\circ} 30$ south latitude. 
Throe aduit specimens, two malos (IBA-UNC,122581-2) and a

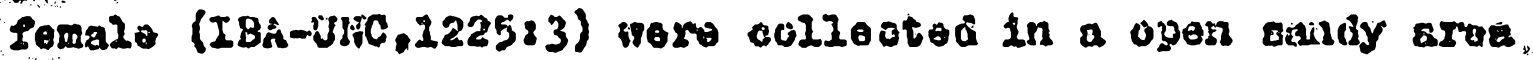

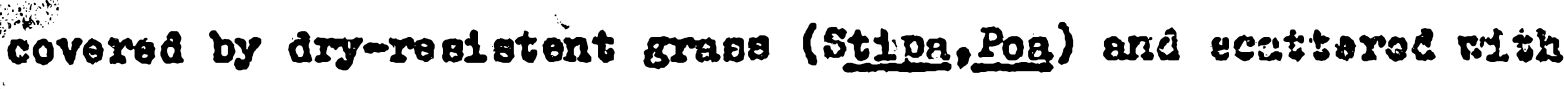

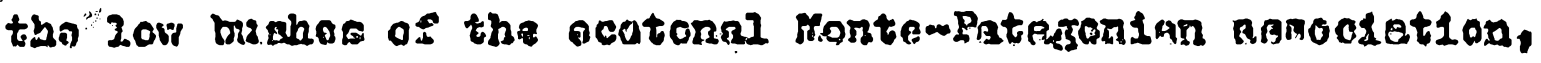

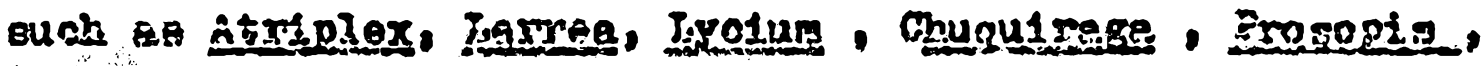

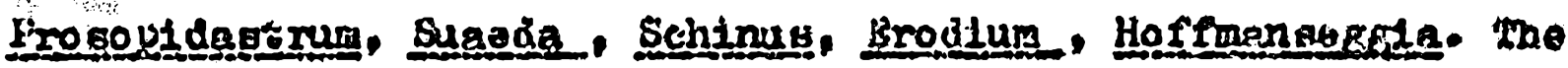

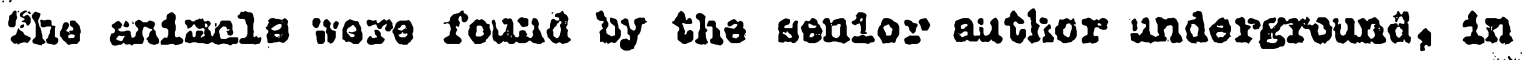

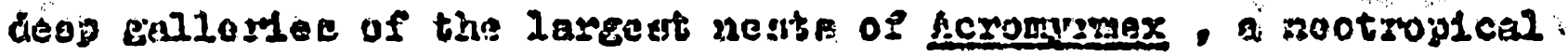

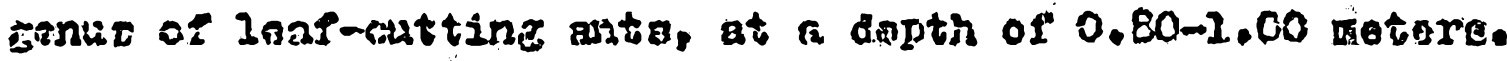

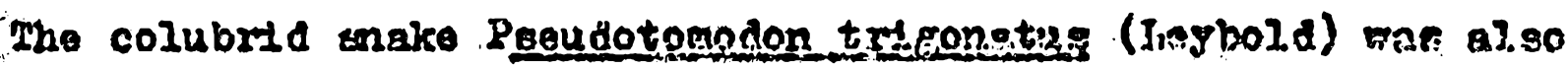
collectea in the camo noots. Southormost syecies of Acromyranex kulit a fromontosy alaped aot abote the exwand, which it coverod oith thick mantlo of fallen 3navos and brancisa. In winter sason guch a layor of orcante matter fos a vaty ofricient shelter against low environmental temperatures, often

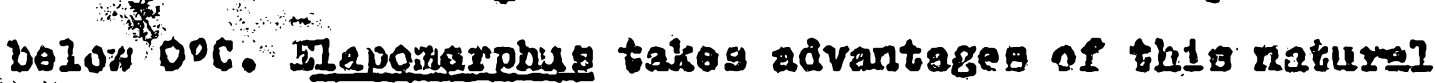
wapport, 1to epeciaene having boen found only in the gullarles under projecting mont1rlos of fallas laves. Tho Intagontan

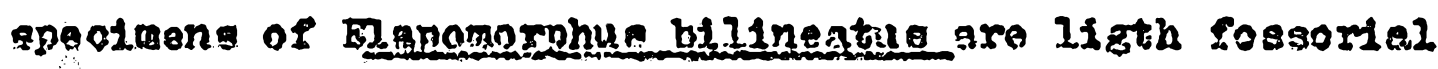
ophidians, gitcking guickly into the sandy soli in captivity, and projably rooding on woras and zaiall arthroposs in tholr

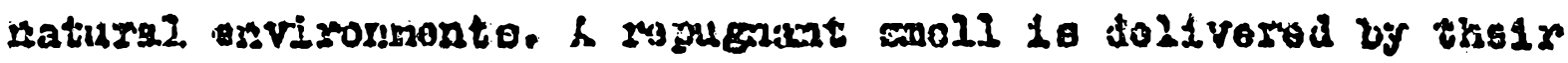

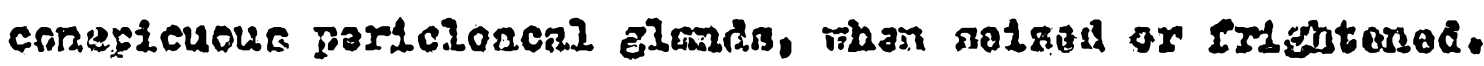

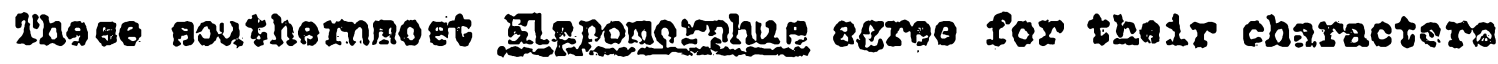

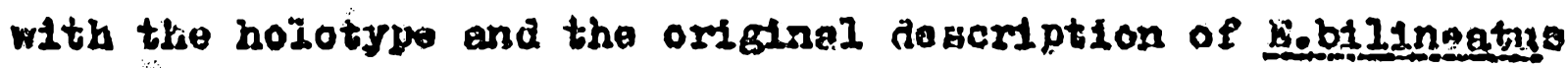

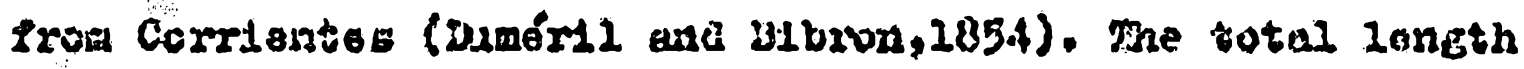

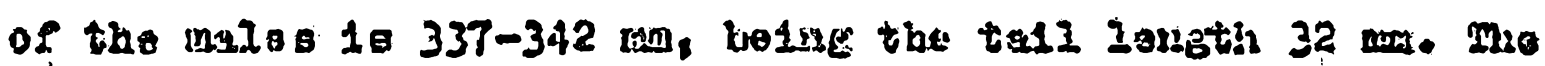
total length of the fomale $19368 \mathrm{~mm}$, boing 1 te tall leneth $25 \mathrm{~mm}$. All the Inoividuals present 15 scale rows at the aldale of the bocyi ventral acalos aro 207-216 in melen, 223 in the Perkiale; subcaudal scales are reepectlvely 33-32 enci 25. Ho norphological or color sex afferences were obsorved $(\$ 16.1, A-B)$. 
The extreme Individual variation of B.lomniscatue, synonym

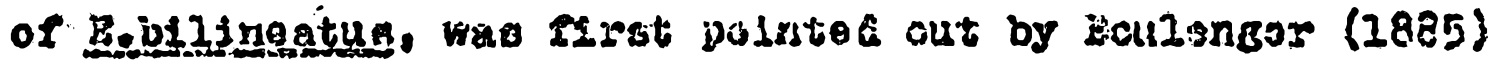

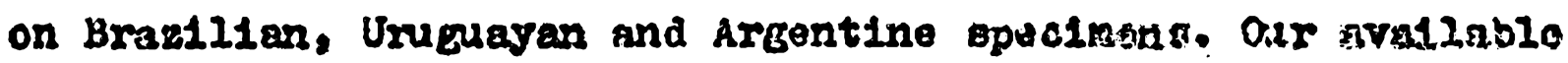

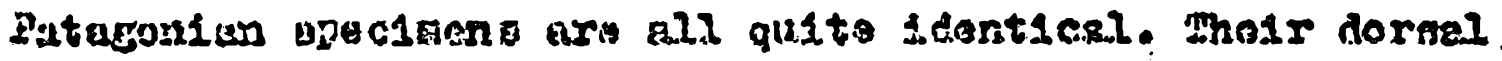

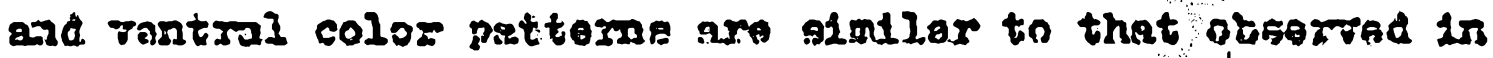
opalnens from rucumán, but they disfor from color pattems

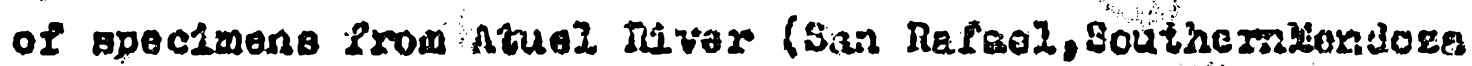

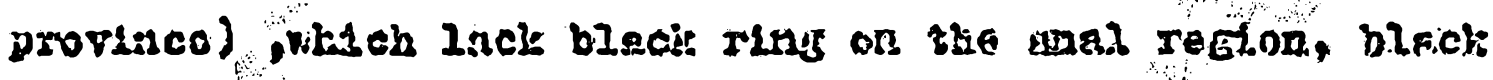

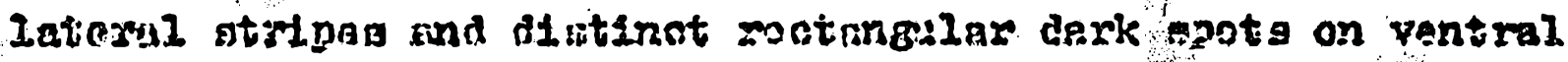

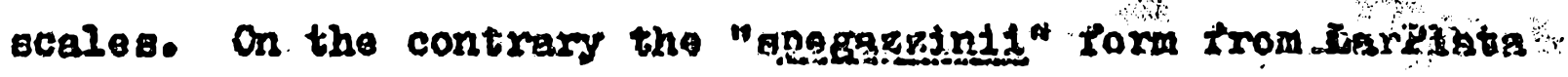

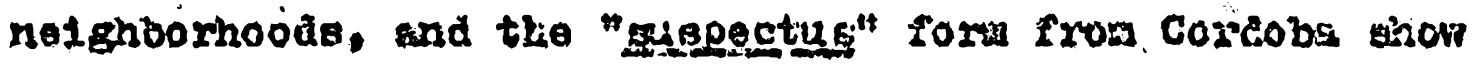

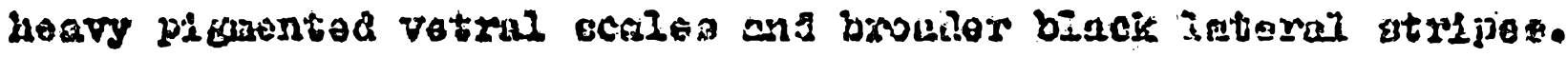

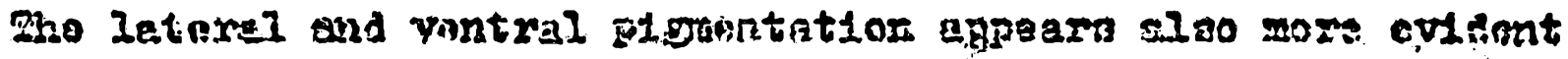

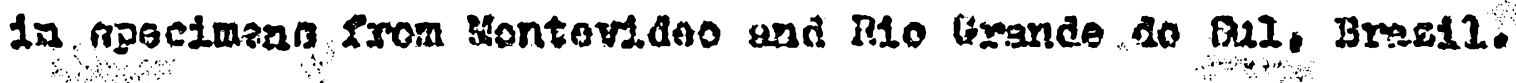
Hereas the yellowi occipltal crosg-bar, black-boriared

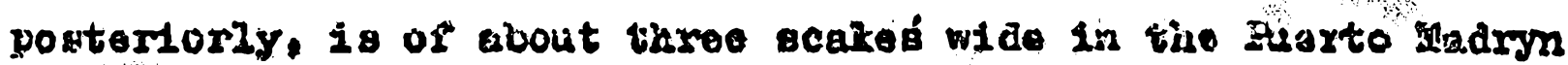
and kfo Atuel opeoimeng, It is narrowor in tho zucumán, Sun

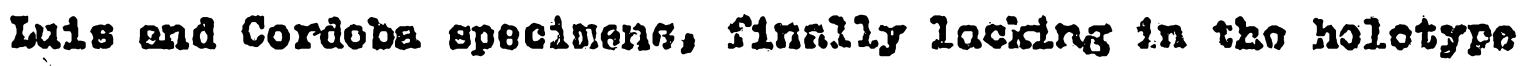

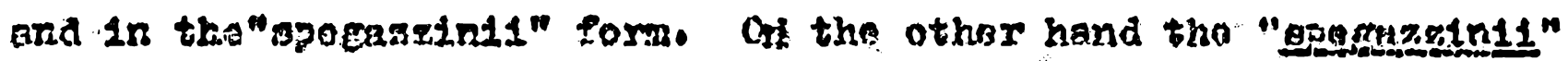
forn alfears from the neariby related populations of fiontevidoc, In which the joizowish orossmbar on treo seale rows of tho

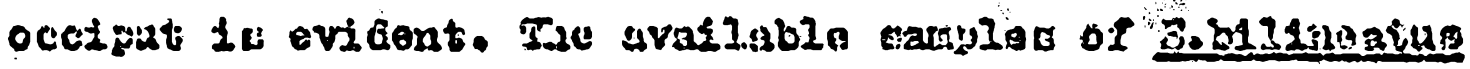

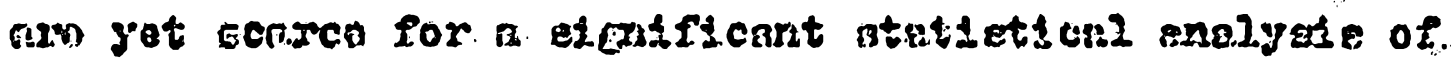
the googrephicel varistion. Hevover, in spite of the unqliegtionable

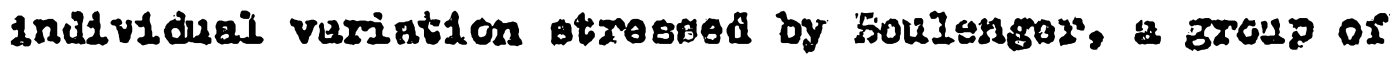
oustarn hoevs pilamentad but nerrowly collared papulationa. und a wetom eroup of 21sth plemented, atstinctly collnron populationo can be probably ougeested.

Tho prosence in the actual Pategonien rango of a abtropical snake such 28 mapomoxphus bilinentus, and 1t coologs, ot 2085 sts k10grograph1cal intereot. It is probabjy a rallo of 
the aucinnt rubtzoptenl ecosystems, or Chacoan Papeoflora, prior to the dramatic environment coranges of the climatic 216istocanfc crisis (SoIbrig,1976). The specibilized

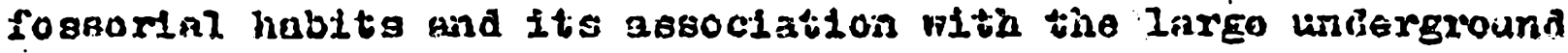
colmunltiss of the ittini, sust have been playing a decisiva role in 1tr proservatiora, probably in tho milder coastal

biotope auch as the relativelg oheltergh, sendy noighiorhood of Luorto kadryn tociay.

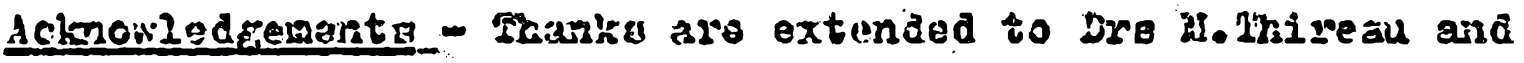
i. Capocaccla for their valdable aid in provicind informations on types in the Fiseum iationale Mietolre Noturalie ô Earis and in the siaeo Civico Storia Naturalo of Genova,respextively. The authors acknowledge with thanks ellso i.li.Savdtzky.U. S. ilationel bussua, Washington, for bibliazrephical advicos, and J.A.V1nI, Untonraty of Thlisiz; Oklahoua, for making useful 3uggestions in the eariy dircusaton of this señot.

\section{JITERATURE CITSD}

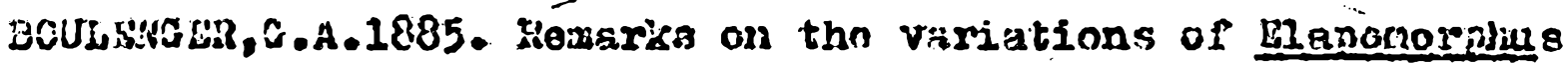

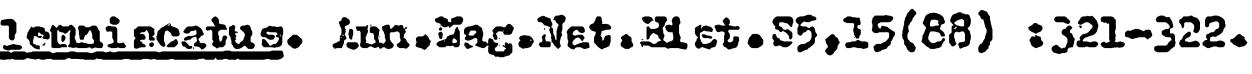

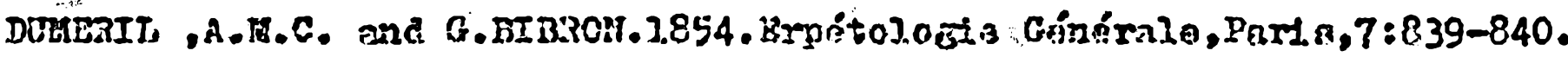
GAJIoRDO, J.H. 2970. Intaregante hallazgo en sierra de Is Ventana.

Camping.Buenos Aires.12: $67-68$.

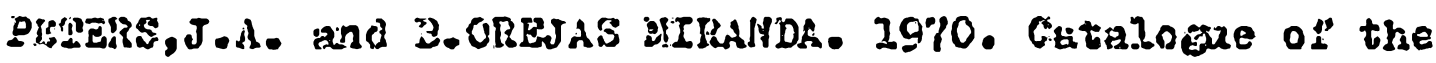

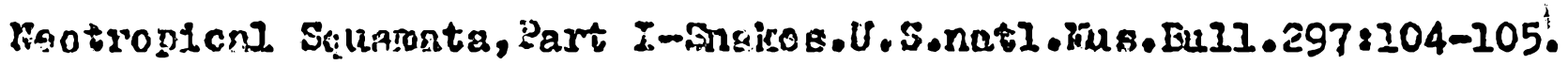
SOT,BRTG ,0.1. 1976. 2-7ne ortfin and Lortetic affinitics of

the south American temperate desert ond pemidegart regione. In:siojution of Donert Hotk.n.w.Goodall id.univ. Texes Prase,Auctin: 7-49.

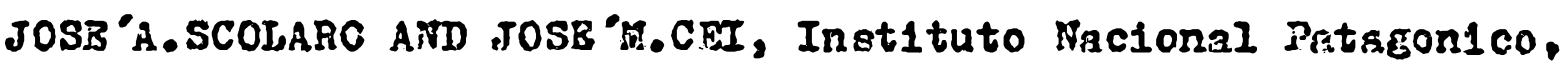
Pyerto Madryn, Chubut, Argentina, and Instituto siologia Animal, Universidad Nacional de Cuyo (IBA-UNC), Rlendoza, Areentina. 